\title{
Unity or diversity? Recent developments in the organization of out of hours general medical services in Scotland
}

\begin{abstract}
Hilary Thomson Department of Community Health Sciences, General Practice, University of Edinburgh, UK, Catherine A O'Donnell Department of General Practice, University of Glasgow, UK, David Heaney Department of Community Health Sciences, General Practice, University of Edinburgh, UK, Katrina Moffat Department of General Practice, University of Glasgow, UK, Sue Ross Mount Sinai Hospital and Samuel Lunenfeld Research Institute, University of Toronto, Canada, Antony Scott Health Economics Research Unit, University of Aberdeen, UK, Neil Drummond Sunnybrook and Women's College Health Sciences Centre, Toronto
\end{abstract}

\begin{abstract}
The objective of this paper is to describe variations in the different models of out of hours general medical services and identify explanations for variation and the possible influence on patient satisfaction and service costs. A cross-sectional survey of all models of out of hours care was undertaken, including co-operatives, deputizing services, practice rotas and rural general practitioners doing their own cover. Fifteen sites were chosen representing 10 models of care, for more detailed case study; 65 semistructured interviews with key informants were conducted within the case study sites. A postal patient satisfaction questionnaire and an economic analysis were also carried out. Out of hours organizations have developed in response to a complex mix of the population served, geography, resources available and political expediency, leading to considerable structural heterogeneity, even within co-operatives. There was little evidence of formal integration with other services. Only the largest co-operatives showed any evidence of utilizing guidelines/protocols or of providing formal staff training. There were clear differences in the structure of out of hours care in urban and rural areas. Increasing the use of centralized call handling and triage will not address the needs of rural GPs, who would still be required to be available for work. Neither patient satisfaction nor costs varied by model of service provision. The English out of hours review has outlined an integrated model of service provision with consistent standards within an accountability framework. It would appear that only the largest organizations will be in a position to address these standards and that they are likely to be inappropriate to the needs of GPs in rural areas.
\end{abstract}

Key words: out of hours care; patient satisfaction; service delivery; service organization

\section{Introduction}

The organization of out of hours general medical services has changed radically for most of the UK population over the past few years, in response to both rising demand for out of hours care (O'Donnell et al., 1999a; Salisbury, 2000) and the increasing strain felt by many general practitioners

Address for correspondence: Hilary Thomson, MRC Social and Public Health Sciences Unit, University of Glasgow, 4 Lilybank Gardens, Glasgow, G12 8RZ, UK.

Email: hilary@msoc.mrc.gla.ac.uk
(GPs) in providing it (Heaney, 1994; Hurwitz, 1994). Agreement between the government and the General Medical Services Committee in 1995 allowed GPs to transfer responsibility for night visits to another principal and gave them the right to decide, on clinical grounds, where care should be provided (Hurwitz, 1995). A development fund was also created to cover the start up and running costs of projects above the level of individual practices.

Since then, co-operatives of principal GPs have become the dominant model of service provision, with 22000 UK GP members of co-operatives in 
1998 (Hallam et al., 1999). However, these vary widely in the levels of service provided, characteristics of the population served, geography of area covered and size of the organization (O'Donnell et al., 1999a; Hallam and Henthorne, 1999; Payne et al., 1997). Additionally, while the rise of cooperatives has been significant, many GPs continue to make significant use of deputizing services or work in smaller $2-3$ practice rotas, while others still provide out of hours cover themselves, particularly in remote and rural areas. Indeed, change has been more difficult to achieve and there is a greater diversity in the type of service provided in rural areas (Robertson, 1997; Ross and Gillies, 1999).

To date, much of the research evaluating out of hours care has compared co-operatives or GPs delivering their own out of hours care with deputising services (Cragg et al., 1997; McKinlay et al., 1997; Salisbury, 1997a; 1997b; 1997c) or with descriptions of co-operatives alone (Bain et al., 1997; Heaney etal., 1997; O'Donnell etal., 1999b). These studies have identified variation in the organization of services and in their response to patient contacts. However, a broader understanding as to why such variation occurs is still lacking. In addition, no study has compared the full range of out of hours care, including rotas and GPs doing their own cover. Such an understanding is necessary if we are to develop meaningful standards for organizations to aspire to.

This study has attempted to carry out such a comparison, examining different models of out of hours general medical services across Scotland. The study comprized two phases. The aim of phase I was to describe the variations in the organizational and operational features of the range of models of out of hours care identified. The aims of phase II were to investigate the explanations for service variation and the possible relationship between patient satisfaction and service costs.

\section{Methods}

\section{Phase I: Survey of out of hours care in Scotland}

In 1998, the Secretary to the Local Medical Committee and the Director of Primary Care (or equivalent) in each Scottish Health Board were contacted in order to identify the structure of gen- eral medical service provision out of hours, accounting for every practice in the area. They were asked to nominate a contact person for each local type of out of hours organization. The contact persons were asked to provide all available documentation for their organization, including demographics of the population served; business plans submitted to the health board; costings of services; results of patient satisfaction surveys; staff surveys; clinical and organizational protocols/ guidelines; and quality assurance and complaints procedures.

These data were collated and used to establish a matrix of out of hours organizations in Scotland. Principal characteristics used to define this matrix were:

- Type of organization: co-operatives were selfdefined (four or more practices providing care from a centre); rotas were defined as groups of two to three practices.

- Size of population served: defined as small (under 50000 ); medium (50000-100 000); or large (more than 100000 ).

- Geography: defined as urban, urban/rural, semirural or rural.

- Deprivation: defined as low, medium or high, based on the Carstairs and Morris score of the local government district(s) covered by the organization (McLoone, 1994).

- Nurse triage: present or absent.

- GP transport provided by the organization: present or absent.

- Patient transport provided by the organization: present or absent.

\section{Phase II: Identification of study sites}

The final matrix depicted 10 different 'models' of out of hours organization (Table 1). Fifteen case study sites, broadly representative of these models, were then selected for detailed investigation. For two of the smaller, rural models more than one site was included to enable sufficient patient satisfaction data to be collected and to allow for variation within this one model type. Each of the sites approached to participate in the study agreed. For small sites, attempts to use local postcode data and population density proved complex. Thus, a purposive sample was selected with predetermined characteristics regarding deprivation and geography confirmed by the sites themselves on selection. 
Table 1 Principal characteristics of out of hours service models identified as specified by the matrix

\begin{tabular}{|c|c|c|c|c|c|c|c|c|}
\hline Model & Description & Deprivation & $\begin{array}{l}\text { Use of } \\
\text { nurse } \\
\text { triage }\end{array}$ & $\begin{array}{l}\text { Provision } \\
\text { of patient } \\
\text { transport }\end{array}$ & $\begin{array}{l}\text { Provision } \\
\text { of GP } \\
\text { transport }\end{array}$ & $\begin{array}{l}\text { Population } \\
\text { covered }\end{array}$ & $\begin{array}{l}\text { Maximum } \\
\text { distance } \\
\text { travelled } \\
\text { by GP or } \\
\text { patient } \\
\text { (miles) }\end{array}$ & $\begin{array}{l}\text { No of } \\
\text { sites } \\
\text { studied }\end{array}$ \\
\hline A & $\begin{array}{l}\text { Small rural and semi-rural } \\
\text { practices providing own cover }\end{array}$ & Low & No & No & No & $\begin{array}{l}\text { From } 1000 \\
\text { to } 7500\end{array}$ & $\begin{array}{l}\text { From } 10 \text { to } \\
30\end{array}$ & 5 \\
\hline B & Medium urban co-operative & Medium & No & No & Yes & 81000 & $4-5$ & 1 \\
\hline $\mathrm{C}$ & Medium urban/rural co-operative & Low & No & No & No & 59000 & 10 & 1 \\
\hline $\mathrm{D}$ & Medium urban co-operative & High & No & No & Yes & 89000 & $4-5$ & 1 \\
\hline$E$ & Large urban co-operative & Medium & Yes & No & Yes & 200000 & $6-8$ & 1 \\
\hline $\mathrm{F}$ & Large urban/rural co-operative & Low & No & No & Yes & 350000 & $\sim 30$ & 1 \\
\hline $\mathrm{G}$ & Large urban co-operative & High & Yes & Yes & Yes & 950000 & $6-8$ & 1 \\
\hline $\mathrm{H}$ & Small urban/rural co-operative & Medium & No & No & No & 61000 & $4-5$ & 1 \\
\hline I & Large deputizing service & High & No & No & Yes & 250000 & $\sim 15$ & 1 \\
\hline $\mathrm{J}$ & Small semi-rural rotas & Low & No & No & No & $\begin{array}{l}11000 \text { and } \\
15000\end{array}$ & $\sim 15$ & 2 \\
\hline
\end{tabular}

Note: columns two to six indicate the principal characteristics of the matrix of out of hours service provision developed from phase I of this study. Columns seven and eight are the specific characteristics of the sites used to represent the model of service provision. Column nine indicates the number of study sites included to represent the model of service provision.

Urban GPs providing their own out of hours care were not included as a study site. From phase I of the survey it was estimated that this group comprized less than $1.5 \%$ of urban GPs. Ethical approval from the Multi-Centre Research Ethics Committee was granted for this study.

\section{Interviews with key informants}

Semistructured interviews were carried out with the lead GP/medical director and, where appropriate, the general manager at each site. Additional interviews were conducted with service GPs and with other staff, including nurses, receptionists and drivers, to investigate different perspectives within the organization. The issues addressed during these interviews were informed by the initial data collected from each site and by issues in the Scottish Office GP Out of Hours Services working group report (GP Out of Hours Services Working Group, 1998). These included the natural history of each organization's development; the management structure and size of organization; call handling and triage; use of nurses; patient transport; integration with other services; access to and use of services; the advantages and disadvantages of current arrangements; and resource use.

A total of 65 interviews were conducted over seven months, with only two GPs declining to be interviewed due to lack of time. All interviews were carried out by the principal researcher (HT) and lasted between one and three hours. Each interview was tape recorded, but not transcribed verbatim. An Access database was developed, reflecting the content of the interview schedule. Tape recordings were replayed in full soon after interview. Items of data extracted and transcribed selectively (but verbatim) in relation to the specific issues of study and were entered directly into the relevant fields of the database. Other themes and areas that emerged during the interviews were added into the database. Each broad area was then analysed across the interview sites by either HT or COD to identify common issues and areas of difference. The audio tapes were archived.

\section{Postal questionnaire to patients}

A postal questionnaire was developed based on those used in previous studies (Drummond et al., 2000; Heaney et al., 1997). The questionnaire was tailored to the age of the service user and type of contact (home visit, telephone or centre visit) and included reasons for and experience of contacting the organization and satisfaction (see Appendix 1). The questionnaire was sent to parents/guardians of 
under-fives and the over-65s. These groups were selected as they are high users of out of hours care (O'Donnell et al., 1999c; Salisbury, 2000). The target number of completed questionnaires was calculated as 200 for each sample group in each site.

Service providers provided lists of consecutive contacts within the required age bands, removing any known deaths. Two single-handed rural sites felt it was impractical to collect enough patient contacts in the time period available, so did not participate in this part of the study. Responses across the other four rural sites that did participate were grouped together for analysis purposes.

A logistic regression analysis was carried out using overall satisfaction as the dependent variable. Variables were considered significant at $P<0.01$.

\section{Economic analysis}

An analysis of the costs of out of hours contacts was conducted based on a postal questionnaire sent to each organization. Information on the quantities of resources used by each organization was collected, and included staff, GP time, transport, communication and call handling, equipment, buildings and overheads. The unit costs of resources were based on market prices and estimates of opportunity costs.

\section{Results}

\section{Phase I: Survey of out of hours care in Scotland}

The survey of health board areas identified 37 co-operatives, 23 rotas and two deputizing services. Of the organizations identified, 29 (78\%) cooperatives, five $(22 \%)$ rotas and both deputizing services provided further data.

At the time, 4032389 people (75\% of the Scottish population) received their out of hours general medical services care from GPs working in cooperatives. The completeness of the data available varied according to the area under consideration and by organization, with co-operatives most likely to supply information requested. For example, all co-operatives were able to supply information on the size of population covered, hours on duty, and the computer system used. Over $75 \%$ of cooperatives could supply information on staffing levels, $69 \%$ had complaints procedures set up, $55 \%$ could supply data on the number of patient contacts they had per annum and the result of those contacts in terms of home visits, centre visits and telephone advice. Governance issues were also examined: $69 \%$ of co-operatives had conducted staff satisfaction surveys, $72 \%$ had developed protocols or guidelines, but only $31 \%$ had developed quality standards. When asked, 79\% had conducted patient satisfaction surveys. However, the quality of these varied greatly with sample sizes ranging from under 100 to 1500 , wide variation in response rates and no standardized format across co-operatives.

Data available from rotas were more limited. One had a complaints procedure in place and was in the process of developing quality standards. The same rota, along with one other, had also carried out a survey of patient satisfaction. Both deputizing services identified had a complaints procedure in place, had developed protocols/guidelines and quality standards and one had conducted a patient satisfaction survey.

\section{Phase II}

Fifteen case study sites were selected to represent the different models of out of hours care initially identified. The characteristics of these sites, in terms of the area and population served, are outlined in Table 1. Further details are contained in Tables 2 and 3. In each, blank cells indicate either that no information was available or that none was elicited during the interviews, due to time limitations.

\section{Urban sites}

The following sections concentrate on data collected from the co-operatives, deputizing services and rotas, principally located in urban areas. Principal characteristics are detailed in Table 2.

\section{Size and management structure}

Co-operative size varied greatly, from eight practices with 41 GPs up to 220 practices with over 600 GPs. The size was determined by several factors, principally the number of GPs wishing to subscribe, the geographical location and the level of health board input. In one co-operative the health board determined the area covered. In this site funds were made available on the condition that both rural and urban areas were included. In another urban/rural co-operative, GPs had to carry out their own home visits if patients lived out with a certain geographical area. 
Table 2 Features of the urban case study sites

\begin{tabular}{|c|c|c|c|c|c|}
\hline \multirow[t]{2}{*}{ Feature } & \multicolumn{5}{|c|}{ Model type } \\
\hline & $\begin{array}{l}\text { B } \\
\text { Medium urban } \\
\text { co-op }\end{array}$ & $\begin{array}{l}\text { C } \\
\text { Medium urban } \\
\text { /rural co-op }\end{array}$ & $\begin{array}{l}\text { D } \\
\text { Medium urban } \\
\text { co-op }\end{array}$ & $\begin{array}{l}\text { E } \\
\text { Large urban } \\
\text { co-op }\end{array}$ & $\begin{array}{l}\text { F } \\
\text { Large urban/ } \\
\text { rural co-op }\end{array}$ \\
\hline $\begin{array}{l}\text { No. of } \\
\text { GPs/practices }\end{array}$ & 12 practices & 42 practices & $56 \mathrm{GPs}$ & $\begin{array}{l}125 \mathrm{GPs} / 36 \\
\text { practices }\end{array}$ & $\begin{array}{l}204 \mathrm{GPs} / 53 \\
\text { practices }\end{array}$ \\
\hline $\begin{array}{l}\text { Staff other } \\
\text { than GPs }\end{array}$ & $\begin{array}{l}\text { Nonmedical } \\
\text { manager, } \\
\text { receptionists, } \\
\text { secretaries, drivers }\end{array}$ & $\begin{array}{l}\text { Nonmedical } \\
\text { manager, } \\
\text { receptionists, } \\
\text { drivers }\end{array}$ & $\begin{array}{l}\text { Nonmedical } \\
\text { manager, } \\
\text { receptionists, } \\
\text { drivers }\end{array}$ & $\begin{array}{l}\text { Triage nurses, } \\
\text { receptionists. } \\
\text { (administrative } \\
\text { staff, drivers, } \\
\text { security and doctor } \\
\text { for home visits } \\
\text { provided by } \\
\text { deputizing service) }\end{array}$ & $\begin{array}{l}\text { Nonmedical } \\
\text { manager, } \\
\text { receptionists, } \\
\text { administrative } \\
\text { staff, drivers, } \\
\text { project co- } \\
\text { ordinator and } \\
\text { traffic controller }\end{array}$ \\
\hline $\begin{array}{l}\text { Centralized call } \\
\text { handling }\end{array}$ & $\begin{array}{l}\text { Yes, calls handled } \\
\text { centrally for most } \\
\text { co-ops in the HB } \\
\text { area, then passed } \\
\text { to appropriate co- } \\
\text { op }\end{array}$ & $\begin{array}{l}\text { No, calls taken by } \\
\text { receptionist, } \\
\text { passed on to GP. } \\
\text { No protocols, use } \\
\text { common sense }\end{array}$ & $\begin{array}{l}\text { No, calls taken by } \\
\text { receptionist, } \\
\text { passed on to GP. } \\
\text { No protocols, use } \\
\text { common sense }\end{array}$ & $\begin{array}{l}\text { No, calls taken by } \\
\text { receptionist, } \\
\text { passed on to nurse } \\
\text { for triage }\end{array}$ & Yes, for HB area \\
\hline $\begin{array}{l}\text { GP transport } \\
\text { provided by } \\
\text { organization }\end{array}$ & $\begin{array}{l}\text { Yes, car, driver, } \\
\text { mobile phones and } \\
\text { pager provided }\end{array}$ & $\begin{array}{l}\text { No, but can use } \\
\text { patient transport if } \\
\text { required }\end{array}$ & $\begin{array}{l}\text { Yes, } 2 \text { cars. } \\
\text { Drivers, mobile } \\
\text { phones, radio } \\
\text { contact and faxes } \\
\text { provided }\end{array}$ & $\begin{array}{l}\text { Yes, drivers and } \\
\text { mobile phones } \\
\text { provided by } \\
\text { deputizing service }\end{array}$ & $\begin{array}{l}\text { Yes, cars, drivers, } \\
\text { ambulance radios, } \\
\text { mobile phones and } \\
\text { pagers }\end{array}$ \\
\hline $\begin{array}{l}\text { Relationship } \\
\text { with A\&E }\end{array}$ & No formal contact & $\begin{array}{l}\text { Some links with } \\
\text { local A\&E }\end{array}$ & $\begin{array}{l}\text { Links with local } A \& \\
E \text { poor. A\&E now } \\
\text { refuses to see } \\
\text { anything that is } \\
\text { not strictly an } \\
\text { emergency }\end{array}$ & $\begin{array}{l}\text { Meet with } A \& E \\
\text { approx twice p.a. }\end{array}$ & $\begin{array}{l}\text { Good relationship, } \\
\text { regular contact to } \\
\text { discuss issues, } \\
\text { e.g., referrals }\end{array}$ \\
\hline $\begin{array}{l}\text { Integrated } \\
\text { working with } \\
\text { other services }\end{array}$ & $\begin{array}{l}\text { Good relations } \\
\text { with district } \\
\text { nurses, social } \\
\text { work, mental } \\
\text { health services. No } \\
\text { formal link with } \\
\text { any }\end{array}$ & $\begin{array}{l}\text { District nursing } \\
\text { based in same } \\
\text { centre but no } \\
\text { formal link; CPNs } \\
\text { about to start out } \\
\text { of hours service; } \\
\text { no integration with } \\
\text { social work }\end{array}$ & None & None & $\begin{array}{l}\text { Yes, CPNs based } \\
\text { within service and } \\
\text { take calls; Nurses } \\
\text { and home carers } \\
\text { based in same } \\
\text { building }\end{array}$ \\
\hline
\end{tabular}

A\&E: Accident and Emergency Department

$\mathrm{CPN}$ : Community Psychiatric Nurse

DN: District Nurse

GMS: General Medical Services

Although the size of the organization impacted on the management structure required, all cooperatives had created an executive/management group that met regularly, with an open meeting for all members annually. One large co-operative had set up three subcommittees, responsible for prescribing, audit or complaints. Other sites del- egated responsibility for arising issues to individual members of the executive committee.

\section{Centralized call handling}

Three out of seven co-ops and one of the rotas had implemented centralized call handling (without triage) to field calls to the appropriate 
Table 2 Continued

\begin{tabular}{|c|c|c|c|c|c|}
\hline \multirow[t]{2}{*}{ Feature } & \multicolumn{5}{|c|}{ Model type } \\
\hline & $\begin{array}{l}\text { G } \\
\text { Large urban } \\
\text { co-op }\end{array}$ & $\begin{array}{l}\mathrm{H} \\
\text { Small urban/ } \\
\text { rural co-op }\end{array}$ & $\begin{array}{l}\text { Large deputizing } \\
\text { service }\end{array}$ & $\begin{array}{l}\mathrm{J} \\
\text { Small semi- } \\
\text { rural rota } 1\end{array}$ & $\begin{array}{l}\mathrm{J} \\
\text { Small semi- } \\
\text { rural rota } 2\end{array}$ \\
\hline $\begin{array}{l}\text { No. of } \\
\text { GPs/practices }\end{array}$ & $\begin{array}{l}\sim 620 \mathrm{GPs} / 220 \\
\text { practices }\end{array}$ & $41 \mathrm{GPs} / 8$ practices & $90 \mathrm{GPs}$ & 2 practices & 9 GPs/3 practices \\
\hline $\begin{array}{l}\text { Staff other than } \\
\text { GPs }\end{array}$ & $\begin{array}{l}\text { Nonmedical } \\
\text { manager, triage } \\
\text { and treatment } \\
\text { room nurses, } \\
\text { receptionists, } \\
\text { administrative } \\
\text { staff, security, } \\
\text { drivers }\end{array}$ & $\begin{array}{l}\text { Receptionists, } \\
\text { office manager, } \\
\text { security }\end{array}$ & $\begin{array}{l}\text { Nonmedical } \\
\text { manager, nurse } \\
\text { practitioners, } \\
\text { receptionist, } \\
\text { administrative } \\
\text { staff, driver, } \\
\text { operators/ } \\
\text { controllers }\end{array}$ & $\begin{array}{l}2 \text { receptionists } \\
\text { for Sat. morning } \\
\text { clinic }\end{array}$ & $\begin{array}{l}\text { Auxiliary nurse, } \\
\text { office manager }\end{array}$ \\
\hline $\begin{array}{l}\text { Centralized call } \\
\text { handling }\end{array}$ & Yes, for city & $\begin{array}{l}\text { No, receptionist } \\
\text { takes calls until } \\
\text { midnight, then GP }\end{array}$ & $\begin{array}{l}\text { No, calls taken by } \\
\text { receptionists; } \\
\text { passed to triage } \\
\text { nurse or GP }\end{array}$ & No & $\begin{array}{l}\text { Yes, use deputizing } \\
\text { service }\end{array}$ \\
\hline $\begin{array}{l}\text { GP transport } \\
\text { provided by } \\
\text { organization }\end{array}$ & $\begin{array}{l}\text { Yes, cars, drivers, } \\
\text { computer link }\end{array}$ & No & $\begin{array}{l}\text { Yes, cars, drivers, } \\
\text { radios, mobiles } \\
\text { and pagers }\end{array}$ & No & $\begin{array}{l}\text { No, use own } \\
\text { transport. Given } \\
\text { pager plus practice } \\
\text { mobile phone }\end{array}$ \\
\hline $\begin{array}{l}\text { Relationship with } \\
\text { A\&E }\end{array}$ & $\begin{array}{l}\text { Good relationship, } \\
\text { particularly at sites } \\
\text { with a primary } \\
\text { care emergency } \\
\text { centre, where A\&E } \\
\text { can pass on GMS } \\
\text { patients }\end{array}$ & $\begin{array}{l}\text { Generally good } \\
\text { relationship; open } \\
\text { access patients } \\
\text { less likely to go to } \\
\text { A\&E with primary } \\
\text { care problems }\end{array}$ & $\begin{array}{l}\text { No formal } \\
\text { relationship }\end{array}$ & No formal links & $\begin{array}{l}\text { Local A\&E closed. } \\
\text { Now have to travel } \\
20 \text { miles to city } \\
\text { casualty }\end{array}$ \\
\hline $\begin{array}{l}\text { Integrated } \\
\text { working with } \\
\text { other services }\end{array}$ & None & None & None & $\begin{array}{l}\text { None. Use same } \\
\text { DNs as daytime } \\
\text { service, so no } \\
\text { problems. Difficult } \\
\text { to contact social } \\
\text { work or CPNs, } \\
\text { although rarely } \\
\text { required }\end{array}$ & None \\
\hline
\end{tabular}

local site. One organization used call handling because the health board had insisted on it. One rota had delegated its call handling to a deputising service.

\section{Triage}

Organizations with centralized call triage were generally positive about its introduction, although some GP members reported missing the opportunity to follow patients through and being unaware of the deciding factors for arranging a consultation. Members of organizations that did not centralize triage were unsure about the advantages and disadvantages of such a system.

In two co-operatives, GPs carried out call triage. However, they often found it to be a stressful experience, as illustrated in the following quote.

you put enormous pressures on your self worrying that you are giving your partner who is visiting excess of calls, again everyone has their own confidence levels of what they deem as an urgent or an appropriate call 
Table 3 Features of the rural case study sites (model A)

\begin{tabular}{|c|c|c|c|c|c|}
\hline \multirow[t]{2}{*}{ Feature } & \multicolumn{5}{|l|}{ Site } \\
\hline & $\begin{array}{l}\text { Single-handed } \\
\text { GP }\end{array}$ & $\begin{array}{l}\text { Single-handed } \\
\text { GP }\end{array}$ & $\begin{array}{l}\text { Island practice with } \\
\text { casualty unit }\end{array}$ & Group practice & $\begin{array}{l}\text { Group practice } \\
\text { with casualty unit }\end{array}$ \\
\hline No. of GPs & $1 \mathrm{GP}$ & $1 \mathrm{GP}$ & 5 or $6 \mathrm{GPs}$ & $3 \mathrm{GPs}$ & $6 \mathrm{GPs}$ \\
\hline $\begin{array}{l}\text { Staff other than } \\
\text { GPs }\end{array}$ & $\begin{array}{l}\text { Practice nurse, } \\
\text { if GP busy }\end{array}$ & & & $\begin{array}{l}\text { Dispenser and } \\
\text { other staff trained } \\
\text { in dispensing }\end{array}$ & \\
\hline $\begin{array}{l}\text { Centralized call } \\
\text { handling }\end{array}$ & $\begin{array}{l}\text { No. Calls taken } \\
\text { by GP or by wife }\end{array}$ & $\begin{array}{l}\text { No. Calls taken } \\
\text { by GP or by wife }\end{array}$ & No & $\begin{array}{l}\text { No, if mobile out } \\
\text { of range someone } \\
\text { at home takes } \\
\text { message. Get } \\
\text { spouses allowance } \\
\text { for rural practice }\end{array}$ & No \\
\hline GP transport & Uses own car & Uses own car & Use own cars & Use own cars & Use own cars \\
\hline $\begin{array}{l}\text { Integrated } \\
\text { working with } \\
\text { other services }\end{array}$ & & $\begin{array}{l}\text { No formal } \\
\text { arrangements }\end{array}$ & $\begin{array}{l}\text { No formal } \\
\text { arrangements; CPN } \\
\text { available on the } \\
\text { island with police } \\
\text { station used as } \\
\text { 'safe place' if } \\
\text { required }\end{array}$ & $\begin{array}{l}\text { No formal } \\
\text { arrangements. } \\
\text { Very difficult to } \\
\text { access social work } \\
\text { or mental health } \\
\text { services }\end{array}$ & $\begin{array}{l}\text { No formal } \\
\text { arrangements. } \\
\text { Used to working } \\
\text { with DNs in } \\
\text { daytime, so no } \\
\text { problem out of } \\
\text { hours }\end{array}$ \\
\hline Other features & $\begin{array}{l}\text { Dispensing facility } \\
\text { at the surgery. } \\
\text { Minor casualty } \\
\text { service } 20 \text { miles } \\
\text { away. If hospital } \\
\text { required, } \\
\text { emergency } \\
\text { volunteer ferry } \\
\text { service must be } \\
\text { called out }\end{array}$ & $\begin{array}{l}\text { Dispensing facility } \\
\text { at the surgery. } \\
\text { Minor casualty } \\
\text { service } 10 \text { miles } \\
\text { away. If hospital } \\
\text { required, } \\
\text { emergency } \\
\text { volunteer ferry } \\
\text { service must be } \\
\text { called out }\end{array}$ & $\begin{array}{l}\text { Community } \\
\text { hospital available. } \\
\text { Patients requiring } \\
\text { larger hospital go } \\
\text { by ferry or are } \\
\text { flown off }\end{array}$ & $\begin{array}{l}\text { Casualty unit and } \\
\text { GP hospital } 30 \\
\text { minutes away; } \\
\text { nearest casualty } \\
\text { with X-ray facilities } \\
1 \text { h away }\end{array}$ & $\begin{array}{l}\text { Run community } \\
\text { hospital and } \\
\text { casualty unit with } \\
\text { the nurses }\end{array}$ \\
\hline
\end{tabular}

or whether social factors come into it and that is what I find the stressful part.

GP member, urban co-operative.

Some GPs felt that nurses would be better at triage, being more likely to stick to protocols. However, only two organizations used nurse triage, both large urban co-ops. These organizations felt that the use of nurse triage was a more efficient way to provide the service although there were some misgivings. Concern was expressed in organizations not utilizing nurses that it would be expensive to implement and the protocols would be overcautious, thus increasing the consultation rate.

\section{Patient transport}

A dedicated patient transport service was available in only one site, a large urban co-operative with high levels of socio-economic deprivation. Perceived advantages of patient transport were that it had reduced unnecessary house calls and was a more efficient way of using GP time.

It is a very, very good leverage to encourage somebody to come down to a centre ... they can't say I don't have transport or I can't afford a taxi.

GP member, large urban co-operative.

Organizations not providing patient transport were concerned about the cost of such a service and the fear that demand would spiral. Some felt that the provision of such a service was not the responsibility of the health service. One GP in an urban co-operative without patient transport made the following remark: 
Yes there are going to be some patients who cannot perhaps afford a taxi, that is not my problem, that is a government problem, a social work problem, I am not a taxi.

GP member, medium urban co-operative.

\section{Contacting the service}

Only three organizations (two co-operatives and one rota) utilized an automatic call-diversion system, connecting patients to the service in one call. In all other cases, the patients received a recorded message giving the number of the on-call service, which they then had to call. If the GP or nurse were unavailable, the patient was called back although in some situations, e.g., chest pain, call from call box, were given priority.

\section{Informing the patient's $G P$}

In most cases, the patient's GP was informed the next morning, often before 08:00 h. This was by fax or van delivery, although one site emailed the practice and another was exploring this as a future possibility. One site faxed only priority calls (e.g., deaths, admissions to hospital) to the practice by 08:00 $\mathrm{h}$ next morning. Information on all other calls was posted to practices in the general mail.

\section{Guidelines/protocols}

There were few examples of formalized guidelines or protocols. Two sites commented that they did not use protocols to guide initial telephone contacts, but relied on the common sense of their receptionists when passing calls to the GP. Those that did exist were in the larger organizations (two large co-ops and the deputizing service) and fell into two groups:

- Management issues - protocols or algorithms to guide nurses during the initial telephone consultation/triage.

- Clinical issues - for example guidelines on the meningitis; managing hot children; chest pain; croup.

\section{Training}

Training was most apparent in the large organizations. Examples included training for receptionists, triage training for nurses and for GPs, training on telephone consultations.

\section{Relationships with other services}

The relationship with A\&E varied from no formal links at all to one with regular meetings to discuss issues of joint interest, e.g., referrals. In one site, A\&E now refused to see any clinical problem that was perceived to be 'primary care'.

Most organizations reported having links with community nursing services, though it was felt that these could be improved. Accessing mental health services and social work was considered to be less than adequate and time consuming. No organization had formally agreed relationships with other health or social services.

\section{Rural sites}

Five sites were designated as small rural sites providing their own cover ( sites A), of which two were single-handed GPs and three were rural group practices (two with attached casualty units). A number of features distinguished the rural sites from any of the others (Table 3). In general, their geographical location dictated the type of service offered. Most were dispensing practices and were remote from casualty services, though two were integrated with a local GP run casualty unit. In three sites, transfer of patients to larger hospital facilities required an emergency volunteer ferry service or airlift. In general, decisions about seeing patients were made by the GP, with no use of nurse triage although one site was keen to implement nurse triage. A number of the GPs also expressed unease about passing on the responsibility for their patients to someone else for triage. Centralized call handling was not used. For both single-handed GPs, their spouses would take calls if they were out, as also sometimes happened with the group practices. This role was formally recognized by a financial allowance for this. Links with other services were not well developed and mostly consisted with informal arrangements with community nursing staff.

\section{Obstacles to uniformity in recent changes across rural and urban areas}

The important changes in service provision were often raized by the rural GPs. Members of some small rural practices and rotas discussed trying to join nearby co-operatives. These approaches were unsuccessful because the co-operatives felt unable to cope with the increase in distance that would result. One area did have a co-operative covering 
an urban centre and a rural hinterland. However, this was due to the health board only funding the co-operative if it covered both. In contrast to this view one member of a small semirural rota suggested that joining a nearby co-operative would be of no benefit due to the increased area they themselves would have to cover.

... just stick with what we've got rather than leaving myself potentially with a huge area to cover with very little in the way of benefit. GP, small semi-rural rota.

This potential clash between urban and rural areas was apparent in other areas as well. A GP member of an urban co-operative discussed how urban GPs have little knowledge or experience of rural practice.

... I can understand why the rural practices feel slightly left out but I think that to force urban general practitioners to go into that environment is probably not to the benefit of the patients nor particularly to the doctors.

GP member, medium urban co-operative

A number of rural GPs interviewed, had considered using centralized call handling and triage. However, this was not seen as a helpful alternative. This service may reduce workload, but it would make no difference to the GPs out of hours commitment, as they would still have to be readily available to deal with the call. This pressure of constant on-call was particularly apparent for the single-handed GPs. Rural GPs reported feeling that they had been treated inequitably with regard to resources and with regard to the wider changes occurring in out of hours provision. Several GPs in these sites suggested that health boards were getting a high level of service for only minimal resources.

\section{Patient satisfaction}

In total, 5382 questionnaires were posted across 13 sites. Of these, 701 patients explicitly declined to participate in the study, 82 questionnaires were returned incomplete, and 238 were returned undelivered. The final response rate was $52.3 \%$ (2284/4361).

The percentage of respondents reporting being either 'fairly satisfied' or 'very satisfied' with their out of hours contact was $87 \%$, ranging from $84 \%$ at a large urban co-operative to $93 \%$ in a small semirural rota. Following logistic regression analysis, using overall satisfaction as the dependent variable, the factors associated with satisfaction were identified (Figure 1). The strongest predictor of satisfaction was whether the doctor or nurse listened to the patient. There was no significant difference in satisfaction by models of out of hours care provision, size of organizations, urban and rural areas, level of deprivation, use of nurse triage, patient or doctor transport.

Figure 1: Factors associated with variations in patient satisfaction

Likely to be more satisfied

- Nurse or doctor listened to them

- More convenient than daytime services

- Problem got better in 7 days after contact

Likely to be less satisfied

- Difficult to leave the house

- Parent of child under 5 years needing medical attention

- Difficulties in getting appointment with own GP

- Told to wait and see if problem gets better

\section{Service costs}

Total annual costs for an organization ranged from $£ 54506$ for a semirural rota covering 15000 patients to $£ 3.2$ million for a GP co-operative covering 350000 patients in a rural health board with one large urban area. Costs per 1000 population varied from $£ 2196$ for a commercial deputizing service to $£ 12120$ for a medium-sized urban/rural co-operative. Between 65 and $84 \%$ of total costs were for GPs' time. The costs of centre contacts varied from $£ 10$ to $£ 16$, home contacts were between $£ 21$ and $£ 60$, and phone contacts varied between $£ 6$ and $£ 11$. There were no obvious relationships between costs and the size and other characteristics of organizations.

\section{Discussion}

This study is the first in the UK to undertake a comparison across the full range of out of hours 
service models, from large co-operatives to singlehanded GPs doing their own on-call. The study combined a cross-sectional survey of out of hours provision in Scotland in 1998, a cost analysis, a patient satisfaction survey and interviews to provide a review of organizational issues and professional perspectives in 15 case study sites. These case study sites were chosen to represent the range of service models used and populations served in Scotland and the total population served by the study sites included in this research cover $42 \%$ of Scotland's population.

There were several limitations to the study. We covered a comprehensive representation of service provision in Scotland, but a large number of interviews was required to achieve this degree of representation. There is a balance to be struck between the number of case study sites to be included in such a study, and the level of detailed information collected in each site. In particular, the variations within rural out of hours services needs further investigation. Untangling the interaction between structure, process and outcome in complex interventions such as this is always problematic. The explanations given in this paper are based on a comprehensive overview and influences at a macro level and are therefore potentially relevant to other areas with similar local variation.

The trade-off between detail and coverage was also problematic in relation to processing the interview data. In our judgement it was not necessary to transcribe each interview in full because the items of data which were germaine to our research questions were identifiable as circumscribed responses to specific interview questions. Selectively transcribing individual verbatim utterances into a database allowed the interviewees' responses to be directly compared and contrasted. While this approach inevitably produces a constricted and less multidimensional interpretation of the data than a full verbatim transcription would have done, it does maintain a systematic and rigorous approach to the task of interpretation, and facilitates an account which is valid, focussed on specific issues and highly relevant.

While the issue of collaboration with other out of hours service providers was incorporated in the interviews, there were no data collected from the other services (e.g., A\&E departments) as this was beyond the scope of the study. This may have meant a partial view of the overall picture of out of hours services in some areas.

\section{Variations in service provision}

The study identified considerable structural heterogeneity in the out of hours study sites. Some of this would be expected, for example a small group practice serving a rural area will clearly be very different from a large urban co-operative. However, even within service models there was heterogeneity. There are likely to be many reasons for this. In some cases, this may be due to the characteristics of the population served. For example, the co-operative providing patient transport served a large, deprived population and use of this service is strongly associated with deprivation (O'Donnell et al., 1999). Geography was also an issue for some sites.

Within co-operatives, it was apparent that issues of clinical governance were more likely to be addressed by the larger organizations. For example, staff training was mainly reported in the large urban co-operatives. Guideline development was fairly limited and was again mainly restricted to large co-operatives. Many organizations did not routinely collect data on response times and, where they were collected, there was a lack of standardisation. Regarding integration with other services, despite some efforts to foster improved formal links there was little evidence of success even among the larger organizations.

The rural areas were also diverse, ranging from single-handed GPs providing their own out of hours care to group practices with attached casualty units. The issues facing rural practice are very different from those affecting out of hours provision in other areas. However, it is unlikely that one solution will be found to the problems facing rural practice in such disparate areas.

Despite striving to fulfil the same remit in terms of out of hours medical provision, it is clear that there are wide variations within and between models and their methods of delivery. The main reasons given for the variations observed are outlined in Figure 2.

\section{Variations in outcomes measured}

Despite the heterogeneity in service provision this appeared to have little effect on patient satisfaction or costs. The costs of providing out of hours care varied considerably across organiza- 
Figure 2: Main determinants of service provision

- Size of population covered

- Levels of deprivation in population covered

- Population density

- Geography of area

- Proximity to A\&E service

- History of local service provision

tions, but with no obvious patterns by type of organization or geography. Variations were more likely to have been determined by differences in the way each organization was set up to meet the local needs of GPs, patients and health boards. Determining which model of care was the most cost-effective was not possible, since data on patients' health outcomes were not collected.

There are several issues with the use of patient satisfaction surveys. Measures of satisfaction are based on an implicit comparison of experience with expectations, and so depend upon expectations as much as experience of the service (Scott and Smith, 1994). Other studies have shown that expectations may be higher for those who have not used out of hours care before, and so expectations differ across types of user, rather than across models of care (Scott et al., 2002). This, however, does not rule out the possibility that the measure of overall satisfaction used may not have been sensitive enough to detect differences across the various models of care.

\section{Policy implications}

Since conducting this work there have been major developments impacting on out of hours care with the introduction of nurse-led telephone advice lines (NHS Direct in England (Floren and Rosen, 1999; Munro et al., 2000); NHS24 in Scotland). A recent review of out of hours service provision in England has outlined plans to integrate NHS Direct with all out of hours care, including general medical services, dental services, social services and A\&E (Independent Review of Out-of-Hours Services in England, 2000). Patients will be dealt with in a single call.
In addition to plans for an integrated service, the review has outlined that this service will have to develop consistent standards within an accountability framework which would reduce variation between service providers. These new standards will address a variety of areas including time taken to answer calls, response times, hard to reach groups, audit and monitoring of patient satisfaction. All providers of out of hours primary medical care will have to meet a range of quality standards in order to be accredited providers of care. As yet, it is unclear whether or not out of hours services in Scotland will follow a similar route. However, the Scottish NHS Plan (NHS Scotland, 2000) makes it clear that integration and accountability are key strategies for the implementation of change in Scotland.

Results from this study would suggest that, at the present time, most out of hours services in Scotland would be unable to meet the recommendations outlined in the English review. This would be particularly true for nonco-operative models of care and for rural areas. At the time of this study, there was little evidence of formal collaboration between out of hours organizations and other service providers. Services were not using guidelines extensively and the amount of staff training was variable. Whether it is necessary for out of hours services to meet all of the standards set out in the English review document needs to be debated. Considerable resources would have to be invested in out of hours organizations to allow them to meet all of the recommended standards and may not affect already high levels of patient satisfaction.

Some of the larger co-operatives in the study which have had relatively higher levels of investment will be able to adjust to changing circumstances but sustained effort and investment will be required to ensure that all out of hours service providers in Scotland are able to do so. In addition, the implementation of NHS24 in Scotland will lead to the development of service level agreements between out of hours organizations and NHS24 which will address many of these targets. However, it is likely that a blanket imposition of all the standards would overwhelm smaller organizations, to the detriment of the clinical service they are trying to provide.

There was a clear distinction in the structure of out of hours care in urban and rural areas and it is likely that further expansion of co-operatives 
across rural areas will not be feasible. The issues facing rural rotas and single-handed GPs require imaginative and innovative approaches.

The potential for increased disparity, despite recommendations for standardisation, is a cause for concern. It is possible that the development of collaborative links between large and smaller organizations may be of benefit. For example, small organizations may not be able to establish their own training programmes or have the resources to develop guidelines but could benefit from access to such developments in the large organizations.

Out of hours organizations have been developed by service providers in response to a complex mix population served, geography, resources available and political expediency, but may not affect patient satisfaction or service costs. The organization of out of hours care in rural areas is markedly different. These issues and the need for locally responsive services will have to be taken into account, if appropriate and sensitive standards are to be set across sites.

\section{References}

Bain, J., Gerrard, L., Russell, A., Locke, R. and Baird, V. 1997: The Dundee out-of-hours co-operative: preliminary outcomes for the first year of operation. British Journal of General Practice 47, 573-74.

Cragg, D.K., McKinlay, R., Roland, M.O., Campbell S.M., Van F. and Hastings A.M. 1997: Comparison of out of hours care provided by patients' own general practitioners and commercial deputising services: a randomized controlled trial. I. The process of care. British Medical Journal 314, 187-88.

Drummond, N., McConnachie, A., O'Donnell, C.A., Moffat, K., Wilson, P. and Ross, S. 2000: Social variation in reasons for contacting general practice out of hours. Implications for daytime service provision? British Journal of General Practice 50, 460-64.

Florin, D. and Rosen, R. 1999: Evaluating NHS Direct. British Medical Journal 319, 5-6.

GP Out of Hours Services Working Group. 1998: GP out of hours services. Working group report. Edinburgh: The Scottish Office Department of Health.

Hallam, L. and Henthorne, K. 1999: Co-operatives and their primary care emergency centres: organization and impact. Combined report on seven case studies. Health Technology Assessment Volume 3, Number 7.

Hallam, L. and Reynolds, M. 1999: In Salisbury, C., Dale, J. and Hallam, L., editors. 24-hour primary care. Abingdon: Radcliffe Medical Press.

Heaney, D., Gorman, D. and Lee, J. 1997: Evaluation of out of hours general medical services in Lothian: doctors' and patients' views. Edinburgh: Dept of General Practice, University of Edinburgh.

Heaney, D., Gorman, D. and Porter, M. 1998: Self-recorded stress levels for general practitioners before and after forming an out-of-hours primary care centre. British Journal of General Practice 48, 1077-78.

Hurwitz, B. 1994: Out of hours: Primary care needs a properly funded, well organized night time service. British Medical Journal 309, 1593-94.

Hurwitz, B. 1995: The new out of hours agreement for general practitioners. British Medical Journal 311, 824-25.

Independent Review of GP Out-of-Hours Services in England. 2000: Raising standards for patients. New partnerships in outof-hours care. London: Department of Health.

McKinlay, R., Cragg, D.K., Hastings, A.M., French, D.P., Manku-Scott, T.K. and Campbell, S.M. 1997: Comparison of out of hours care provided by patients' own general practitioners and commercial deputising services: a randomized controlled trial. II. The outcome of care. British Medical Journal 314, 190-93.

McLoone, P. 1994: Carstairs scores for Scottish postcode sectors from the 1991 census. Glasgow: Public Health Research Unit, University of Glasgow.

Munro, J., Nicholl, J., O'Cathain, A. and Knowles, E. 2000: Impact of NHS Direct on demand for immediate care: observational study. British Medical Journal 321, 150-51.

NHS Scotland. 2000: Our national plan. A plan for action, a plan for change. Edinburgh: NHS Scotland, 1-97.

O'Donnell, C.A., Drummond, N. and Ross, S. 1999a: Out of hours primary care: a critical overview of current knowledge. Health Bulletin 57, 276-84.

O’Donnell, C.A., McConnachie, A., Moffat, K., Drummond, N., Wilson, P. and Ross, S. 1999b: Cross sectional study of social variation in use of an out of hours patient transport service. British Medical Journal 318, 566-67.

O’Donnell, C.A., McConnachie, A., Moffat, K., Drummond, N., Wilson, P. and Ross, S. 1999c: Out of hours care in the UK generalizability of research findings. Journal of Public Health Medicine 21, 482-83.

Payne, F., Jessopp, L. and Dale, J. 1997: Second national survey of GP co-operatives: a report. Out of Hours Project, Dept. of General Practice and Primary Care. London: King's College School of Medicine and Dentistry.

Robertson, D.A.G.C. 1997: GP co-operatives - Don't serve rural patients well. British Medical Journal 314, 976.

Ross, S. and Gillies, J.C.M. 1999: Characteristics and career intentions of Scottish rural and urban GP registrars: cause for concern? Health Bulletin 57, 44-52.

Salisbury, C. 1997a: Observational study of a general practice out of hours co-operative: measures of activity. British Medical Journal 314, 182-86.

Salisbury, C. 1997b: Postal survey of patients' satisfaction with a general practice out of hours co-operative. British Medical Journal 314, 1594-98.

Salisbury, C. 1997c: Evaluation of a general practice out of hours 
co-operative: a questionnaire survey of general practitioners. British Medical Journal 314, 1598-99.

Salisbury, C. 2000: The demand for out-of-hours care from GPs: a review. Family Practice 17, 340-47.

Scott, A. and Smith, R.D. 1994: Keeping the customer satisfied: issues in the interpretation and use of patient satisfaction surveys. International Journal for Quality in Health Care 6, 353-59.

Scott, A., Watson, M.S. and Ross, S. 2003: Eliciting preferences of the community for out of hours care provided by general practitioners: a stated preference discrete choice experiment. Social Science and Medicine 56, 803-14.

\section{Appendix 1 Patient satisfaction questionnaire}

How satisfied were you with:
(a) The telephone contact?
(b) The location of the centre?
(c) The waiting time to be seen?
(d) The treatment you received?
(e) The overall service?

$\begin{array}{llll}\begin{array}{l}\text { Very } \\ \text { satisfied }\end{array} & \begin{array}{l}\text { Fairly } \\ \text { satisfied }\end{array} & \text { Uncertain } & \begin{array}{l}\text { Not very } \\ \text { satisfied }\end{array}\end{array}$

at all 